\title{
Effect of Varying Dietary Cation-Anion Difference (DCAD) on In Vitro Nutrient Digestibility
}

\author{
Harneet Kour ${ }^{1}$, Ravinder Singh Grewal ${ }^{1 *}$, Jaspal Singh Lamba ${ }^{1}$, Jasmine Kaur ${ }^{1}$ and Shashi Nayyar ${ }^{2}$ \\ ${ }^{1}$ Department of Animal Nutrition, College of Veterinary Sciences, Guru Angad Dev Veterinary and Animal Science University, \\ Ludhiana (Punjab), INDIA \\ ${ }^{2}$ Department of Veterinary Physiology and Biochemistry, C.O.V.S, GADVASU, Ludhiana (Punjab), INDIA \\ "Corresponding author: RS Grewal; E-mail: ravigrewal71@yahoo.co.in
}

Received: 09 July, 2021

Revised: 24 July, 2021

Accepted: 29 July, 2021

\begin{abstract}
An extensive in vitro experiment was planned to study the effect of varying levels of dietary cation-anion difference (DCAD) on in vitro nutrient digestibility and its effect on rumen microbes. For experiment, two negative DCAD diet were prepared from conventional prepartum total mixed ration (TMR) supplemented with anionic salt @ -50 (Low negative; LN), -100 (High negative; HN) and a negative control without any anionic supplementation (CON1) was used for comparison. Similarly, two positive DCAD diet were prepared from conventional postpartum TMR with cationic salt supplementation@ @200 (Low positive; LP), +400 (High positive; HP) along with positive control (CON2) diet. DCAD diets was formulated using equation $(\% \mathrm{Na} / 0.023+\% \mathrm{~K} / 0.039)-(\% \mathrm{Cl} / 0.0355+\% \mathrm{~S} / 0.016) \mathrm{mEq} / 100 \mathrm{gm}$ of DM. Analysis of result revealed that negative DCAD (LN \& HN) had better PF (mg/ml), $\mathrm{NH}_{3}-\mathrm{N} \%$ and EMMP \% then CON1 diet $(p<0.01)$ and highest value was observed with HN DCAD suggesting that negative (especially HN) DCAD during prepartum can be helpful in improving rumen nutrient digestibility and microbial protein synthesis. Whereas, CON2 had better in vitro parameters $(p<0.05)$ than positive DCAD (LP \& HP) but no deleterious effect was observed, thus, suggesting that, both positive and negative DCAD are safe for use in ruminants.
\end{abstract}

\section{HIGHLIGHTS}

(0 Two negative $(-50 \&-100)$ and positive $(+200 \&+400)$ DCAD diets were prepared.

0 Negative DCAD diet had better in vitro nutrient digestibility then control.

0 Addition of cations and anions in ruminant ration is safe.

Keywords: Digestibility, in vitro, negative DCAD, positive DCAD

Transition period ( 3 weeks before and 3 weeks after parturition) marks an important period, during which animal undergoes through enormous metabolic and hormonal changes (Abdulkareem, 2013). During this time, animal is at high risk of developing various metabolic diseases but certain manipulation in cation-anion of animal's ration can prevent the development and occurrence of such diseases. Dietary cation-anion difference (DCAD) is one such concept which is more than 20 years old. It is an index of concentration of major minerals in the ration which indeed, determine the acid-base status of the animal body.
As a part of effective and advance ration formulation program, it is common to add anions or to reduce the concentration of positive cations in diet of advanced prepartum animals and to make the DCAD level of the diet negative, as it induces metabolic acidosis and increases calcium mobilization during that period. Whereas, it is

How to cite this article: Kour, H., Grewal, R.S., Lamba1, J.S., Kaur, J. and Nayyar, S. (2021). Effect of Varying Dietary Cation-Anion Difference (DCAD) on In Vitro Nutrient Digestibility. J. Anim. Res., 11(04): 737-740. Source of Support: None; Conflict of Interest: None क्) 
customary to add positive cations or make the DCAD level of the diet positive in postpartum period, to compensate for high amount of acid produced during early lactation and increase dry matter intake (DMI) but the internal effect of DCAD on rumen environment is still unexplored. A lot of in vivo experiments have been conducted on dairy animals but in vitro studies on effect of DCAD on nutrient utilization is very less. Hence, the present project was designed to study the effect of varying levels of DCAD on in vitro rumen fermentation, gas production and nutrient digestibility parameters. It will help us to understand the mechanism behind the effects of DCAD manipulation.

\section{MATERIALS AND METHODS}

\section{DCAD estimation of feed}

The present study was conducted in the Department of Animal Nutrition, Guru Angad Dev Veterinary and Animal Sciences University, Ludhiana. Estimation of cations and anions of the feed and fodder (conventional prepartum and postpartum TMR) were done by Punjab Biotechnology Incubator (PBTI), Mohali and amount of salt used (ammonium chloride for negative DCAD and disodium hydrogen phosphate for positive DCAD) to achieve required levels of DCAD is given in table 1 .

Table 1: DCAD level of TMR and dose of salt

\begin{tabular}{llll}
\hline $\begin{array}{l}\text { Sl. } \\
\text { No }\end{array}$ & DCAD of sample & $\begin{array}{l}\text { Salt added in } \\
\text { total diet }\end{array}$ & $\begin{array}{l}\text { Resultant DCAD of } \\
\text { the diet }\end{array}$ \\
\hline 1 & Prepartum TMR & $\mathrm{LN}=73 \mathrm{gm}$ & $-50.2321 \mathrm{mEq} / \mathrm{kg} \mathrm{DM}$ \\
& $=+63.469 \mathrm{mEq} /$ & $\mathrm{HN}=105 \mathrm{gm}$ & $-100.082 \mathrm{mEq} / \mathrm{kg} \mathrm{DM}$ \\
& $\mathrm{kg} \mathrm{DM}$ & & \\
2 & $\begin{array}{l}\text { Postpartum TMR } \\
=+140.94 \mathrm{mEq} /\end{array}$ & $\mathrm{LP}=50 \mathrm{gm}$ & $+199.64 \mathrm{mEq} / \mathrm{kg} \mathrm{DM}$ \\
& $\mathrm{HP}=150 \mathrm{gm}$ & $+317.045 \mathrm{mEq} / \mathrm{kg} \mathrm{DM}$ \\
& $\mathrm{kg} \mathrm{DM}$ & & \\
\hline
\end{tabular}

\section{Sample preparation}

The in vitro gas production was assessed according to Menke and Steingass (1988). $375 \pm 5 \mathrm{mg}$ of total mixed rations (TMR) given to prepartum animals, along with varying levels of ammonium chloride (anionic salt) was supplemented@-50 (Low Negative; LN) and-100 (High Negative; HN) mEq/kg DM. The syringes containing sample in triplicate were kept in water bath at $39^{\circ} \mathrm{C}$ for 24 h. Another set of TMR (375 $\pm 5 \mathrm{mg})$ given to postpartum animals along with cationic salt @ +200 (Low Positive; LP) and +400 (High Positive; HP) $\mathrm{mEq} / \mathrm{kg}$ DM. Two control TMR (negative control; $\mathrm{CON} 1$ and positive control; CON2) respectively for negative and positive DCAD were used for comparison. Rumen fistulated male buffaloes were used as a donor for rumen liquor.

\section{Procedure}

All the chemicals were added to rumen liquor and syringes were filled with $30 \mathrm{ml}$ of SRL (strained rumen liquor): buffer and maintained at $39^{\circ} \mathrm{C}$. The contents in all the syringes were swirled at $1 \mathrm{~h}$ interval and after $8 \mathrm{~h}$ the volume of gas was recorded and gas was removed. After $24 \mathrm{~h}$ volume gas produced in each syringe was recorded. The amount of gas produced was used to calculate the $\mathrm{ME}$ value. After $24 \mathrm{~h}$ the $\mathrm{NH}_{3}-\mathrm{N}, \mathrm{OM}$ and NDF of residue were determined.

1. $\mathrm{ME}(\mathrm{MJ} / \mathrm{kg} \mathrm{DM})=1.06+0.157 \mathrm{G}(\mathrm{ml} / 200 \mathrm{mg} \mathrm{DM})$ $+0.0084 \mathrm{CP}+0.022 \mathrm{EE}-0.0081$ ash (Menke et al., 1979) where, $\mathrm{ME}=$ Metabolizable energy, $\mathrm{G}=\mathrm{Net}$ gas production, $\mathrm{ml} / 200 \mathrm{mg} \mathrm{DM}, \mathrm{CP}=$ Crude protein, $\mathrm{g} / \mathrm{g} \mathrm{DM}, \mathrm{EE}=$ Ether extract, $\mathrm{g} / \mathrm{g}$.

2. The $\%$ ammonia nitrogen $\left(\mathrm{NH}_{3}-\mathrm{N} \%\right)=($ Vol. of acid used $\times$ Normality of acid $\times 0.014) / S R L, m l) \times 100$ (AOAC, 2007)

3. Net Gas Production (NGP) /200 mg DM = NGP (ml)/ sample weight*200.

\section{Statistical analysis}

Data were analyzed by simple ANOVA, as described by Snedecor and Cochran, (1994), by using SPSS (2016) software. The differences in means were tested by Duncan's multiple range test.

\section{RESULTS AND DISCUSSION}

\section{Effect of negative DCAD on in vitro parameters}

Results of in vitro experiment is given in table 2. It was observed that $\mathrm{NH}_{3}-\mathrm{N}$, Partioning Factor (PF), EMMP were significantly higher in TMR with LN and HN DCAD levels compared to CON1 TMR $(p<0.01)$. All these 
parameters were comparatively highest in HN TMR then LN TMR, suggesting better in vitro digestibility with HN TMR. Although the difference was not significant between two negative DCAD groups $(p>0.05)$.

Partioning factor (PF; mg/dl) was significantly higher in negative DCAD group then CON1 TMR $(p<0.01)$ and highest with HN $(3.54 \mathrm{mg} / \mathrm{ml})$ TMR then LN $(3.46 \mathrm{mg} /$ $\mathrm{ml}) \mathrm{TMR}$, but difference between two is non-significant $(p>0.05)$. A higher partitioning factor signifies higher efficiency of microbial protein synthesis (Thirumalesh and Krishnamoorthy, 2013). This signifies that negative DCAD level in prepartum diet increases efficiency of microbial protein synthesis.

Other parameters like NGP/200 mg DM and DMD \% were less significant between the control and two treatment groups. He et al. (2019) reported NGP/200 mg of DM as an indicator of the amount of gas produced and rate of feed digestion. It thus suggests that, addition of anion to the TMR did not hamper the normal ruminal digestion process and it is thus safe for the animals under prescribed amounts. Yang et al. (2021) also observed no deleterious effect of negative DCAD on rumen fermentation parameters. Fortnight net gas production (NGP/200 mg DM) of LN, $\mathrm{HN}$ and CON1 TMR is given in Fig 1.

Table 2: In vitro parameters of prepartum TMR with negative DCAD

\begin{tabular}{lllll}
\hline Variables & CON1 & LN & HN & P value \\
\hline $\begin{array}{l}\text { NGP/200 } \\
\mathrm{mg} \mathrm{DM}\end{array}$ & $35.66 \pm 0.88$ & $35.70 \pm 2.20$ & $35.22 \pm 1.72$ & 0.832 \\
$\mathrm{NH}_{3}-\mathrm{N}$, & $27.36 \pm 3.51^{\mathrm{a}}$ & $30.95 \pm 2.98^{\mathrm{b}}$ & $33.44 \pm 2.01^{\mathrm{b}}$ & 0.004 \\
$\mathrm{mg} / \mathrm{dl}$ & & & & \\
$\mathrm{OMD} \%$ & $64.97 \pm 3.40$ & $68.43 \pm 5.62$ & $69.11 \pm 4.78$ & 0.381 \\
$\mathrm{PF}, \mathrm{mg} / \mathrm{ml}$ & $3.33 \pm 0.09^{\mathrm{a}}$ & $3.46 \pm 0.09^{\mathrm{ab}}$ & $3.54 \pm 0.12^{\mathrm{b}}$ & 0.013 \\
$\mathrm{NDFD}, \%$ & $39.27 \pm 7.46$ & $46.87 \pm 9.43$ & $48.82 \pm 7.05$ & 0.166 \\
$\mathrm{MMP}, \mathrm{mg}$ & $75.75 \pm 7.53$ & $85.19 \pm 10.12$ & $89.05 \pm 10.12$ & 0.104 \\
$\mathrm{EMMP}, \%$ & $33.93 \pm 1.91^{\mathrm{a}}$ & $36.55 \pm 1.77^{\mathrm{b}}$ & $37.89 \pm 2.30^{\mathrm{b}}$ & 0.012 \\
$\mathrm{DMD}, \%$ & $67.93 \pm 3.31$ & $71.373 \pm 5.27$ & $72.0 \pm 4.43$ & 0.342 \\
$\mathrm{ME}, \mathrm{MJ} / \mathrm{kg}$ & $13.22 \pm 0.35$ & $12.08 \pm 0.59$ & $12.62 \pm 0.47$ & 0.170 \\
$\mathrm{DM}$ & & & & \\
\hline
\end{tabular}

${ }^{\mathrm{ab}}$ Means with different superscripts within a row differ significantly $(\mathrm{P}<0.05)$.

\section{Effect of positive DCAD on in vitro parameters}

Results of in vitro experiment with positive DCAD is given in table 3. It was observed that values of $\mathrm{NH}_{3}-\mathrm{N}$, OMD, NDFD, MMP, DMD and ME were significantly higher in CON2 compared to LP and HP TMR $(p<0.05)$. The difference between two positive DCAD levels was less significant $(p>0.05)$.

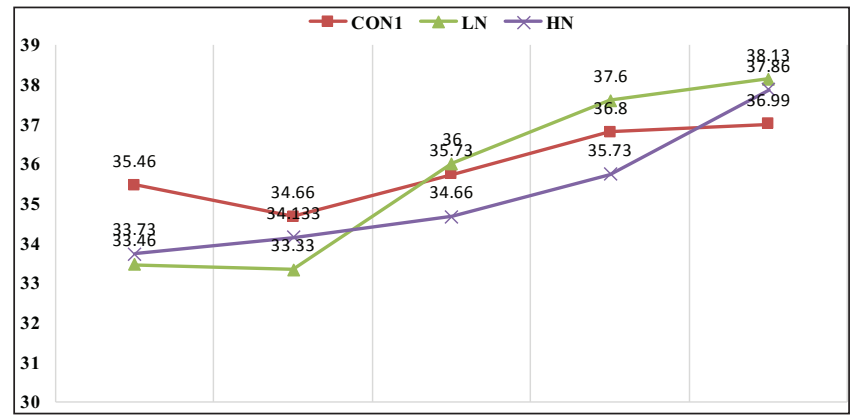

Fig. 1: Fortnight NGP/200 gm with negative DCAD

The ME value varied from 9.52 to $12.24 \mathrm{MJ} / \mathrm{kg} \mathrm{DM}$ for positive DCAD with an average of $11.00 \mathrm{MJ} / \mathrm{kg}$ DM which was similar for both the levels of positive DCAD levels, which signifies that both the levels of positive DCAD salts provide similar amount of energy. Lower ME level may be a reason for higher DMI when positive cations are added to the diet (Huang et al., 2014). Barabad et al. (2020) also observed that +250 DCAD as an appropriate supplement to dairy cow. Fortnight net gas production (NGP/200 mg DM) of LP, HP and CON2 TMR is given in Fig. 2.

Table 3: In vitro parameters of postpartum TMR with positive DCAD

\begin{tabular}{lllll}
\hline Variables & CON2 & LP & HP & P value \\
\hline $\begin{array}{l}\text { NGP/200 } \\
\text { mg DM }\end{array}$ & $35.60 \pm 3.56$ & $33.11 \pm 3.40$ & $33.11 \pm 1.17$ & 0.340 \\
$\mathrm{NH}_{3}-\mathrm{N}$, & $34.64 \pm 4.92^{\mathrm{b}}$ & $28.38 \pm 1.56^{\mathrm{ab}}$ & $24.32 \pm 0.16^{\mathrm{a}}$ & 0.000 \\
$\mathrm{mg} / \mathrm{dl}$ & & & & \\
$\mathrm{PF}, \mathrm{mg} / \mathrm{ml}$ & $3.68 \pm 0.07$ & $3.53 \pm 0.34$ & $3.49 \pm 0.08$ & 0.439 \\
$\mathrm{OMD} \%$ & $71.16 \pm 6.38^{\mathrm{b}}$ & $63.44 \pm 2.31^{\mathrm{a}}$ & $63.21 \pm 1.21^{\mathrm{a}}$ & 0.006 \\
$\mathrm{NDFD}, \%$ & $47.80 \pm 3.46^{\mathrm{b}}$ & $45.00 \pm 2.42^{\mathrm{ab}}$ & $43.39 \pm 1.92^{\mathrm{a}}$ & 0.023 \\
$\mathrm{MMP}, \mathrm{mg}$ & $98.65 \pm 7.92^{\mathrm{b}}$ & $80.92 \pm 12.99^{\mathrm{a}}$ & $80.49 \pm 2.92^{\mathrm{a}}$ & 0.015 \\
$\mathrm{EMMP} \%$ & $40.22 \pm 1.18$ & $37.21 \pm 5.93$ & $37.09 \pm 1.72$ & 0.409 \\
$\mathrm{DMD} \%$ & $73.46 \pm 5.87^{\mathrm{b}}$ & $66.57 \pm 2.19^{\mathrm{a}}$ & $66.311 \pm 1.16^{\mathrm{a}}$ & 0.008 \\
$\mathrm{ME}, \mathrm{MJ} /$ & $12.80 \pm 0.21^{\mathrm{b}}$ & $11.00 \pm 0.99^{\mathrm{a}}$ & $11.00 \pm 0.33^{\mathrm{a}}$ & 0.001 \\
$\mathrm{~kg} \mathrm{DM}$ & & & & \\
\hline
\end{tabular}

ab Means with different superscripts within a row differ significantly $(\mathrm{P}<0.05)$. 


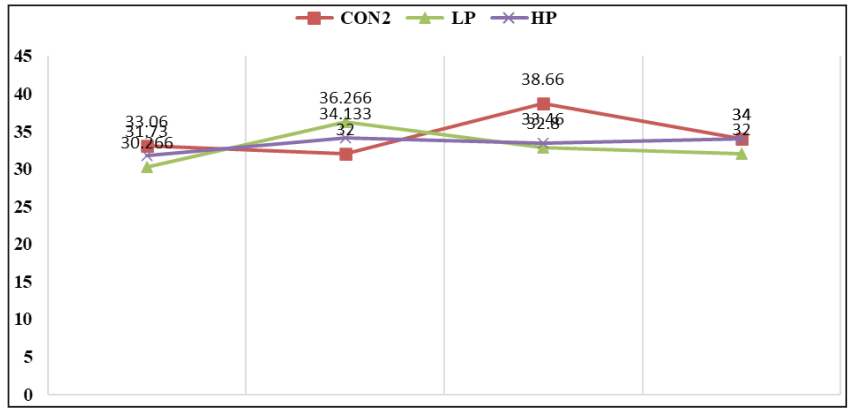

Fig. 2: Fortnight NGP/200 gm with positive DCAD

\section{SUMMARY}

It can be concluded that varying level of DCAD do not have any deleterious effect on nutrient digestibility and rumen fermentation, instead negative DCAD during prepartum can be helpful in improving rumen nutrient digestibility of the feed whereas, positive DCAD during postpartum can increase the dry matter intake of the animal. It is thus, suggested that, addition of anion or cation to the TMR do not hamper the normal ruminal digestion process and it is thus safe for the animals under prescribed amounts.

\section{REFERENCES}

Abdulkareem, T.A. 2013. Some hematological and blood biochemical attributes of Iraqi riverine buffaloes (Bubalus bubalis) around calving and postpartum periods. Al-Anbar J. Vet. Sci., 6(1): 143-150.

AOAC. 2007. Official methods of analysis. $18^{\text {th }}$ Ed., Gaithersburg: Association of Official Analytical Chemists.

Barabad, Y.F., Ghiasi, S.E. and Torbati, M.B.M. 2020. Effect of DCAD on rumen fermentation parameters. Iran. J. Anim. Sci Res., 12(2): 181-195.
He, Y., Cone, J.W., Hendriks, W.H. and Dijkstra, J. 2019. Relationships between chemical composition and in vitro gas production parameters of maize leaves and stem. J. Anim. Physiol. Nutr., 104: 12-21.

Huang, W., Tian, Y., Wang, Y., Simayi, A., Yasheng, A., Wu, Z., Li, S. and Cao, Z. 2014. Effect of reduced energy density of close-up diets on dry matter intake, lactation performance and energy balance in multiparous Holstein cows. J. Anim. Sci. Biotechno., 5(1): 30.

ICAR, 2013. Handbook of Animal Husbandry. $4^{\text {th }}$ Ed., Department of Agricultural Research and Education, Government of India, New Delhi, pp. 43.

Menke, K.H. and Steingass, H. 1988. Estimation of energetic feed value obtained by chemical analysis and in vitro gas production using rumen fluid. Anim. Res. Dev., 28: 7-55.

Menke, K.H., Raab, L., Salewski, A., Steingass, H., Fritz, D. and Schneider, W. 1979. The estimation of the digestibility and metabolizable energy content of ruminant feedstuffs from the gas production when they are incubated with rumen liquor in vitro. J. Agric. Sci., 92: 217-22.

Snedecor, G.W. and Cochran, W.G. 1994. Statistical Methods. $11^{\text {th }}$ Ed., The Iowa State University Press, Ames, IA, pp. 267.

SPSS. 2016. Statistical Packages for Social Sciences Version 21.0. SPSS Inc. Chicago, IL, USA.

Thirumalesh, T. and Krishnamoorthy, U. 2013. Rumen microbial biomass synthesis and its importance in ruminant production. Int. J. Livest. Res., 3(2): 5-26.

Yang, K., Tian, X., Ma, Z. and Wu, W. 2021. Feeding a negative dietary cation-anion difference to female goats is feasible, as indicated by the non-deleterious effects on rumen fermentation and rumen microbial population and increased plasma calcium level. Animals, 11(664): 1-14. 